\title{
Reflections on the Academic Status of Lexicography
}

\author{
Sven Tarp, Department of Afrikaans and Dutch, University of Stellenbosch, \\ Stellenbosch, South Africa, and Centre for Lexicography, Aarhus School of \\ Business, University of Aarhus, Aarhus, Denmark (st@asb.dk)
}

\begin{abstract}
Two main camps have been formed with regard to the philosophical and academic status of lexicography: one considering lexicography an independent scientific discipline, and the other opposing such a scientific status. This article discusses some of the arguments from the second camp and argues that lexicography should be considered an independent scientific discipline. The argumentation is based on the fact that the subject field of lexicography is different from the subject fields of any other discipline, including linguistics. In this sense, the concept of a lexicographical work is broader than the more reduced concept of a dictionary. Lexicographical works, including dictionaries, are considered cultural artefacts and utility tools produced in order to meet punctual information needs detected in society. In this way, they have during the millenniums covered almost all spheres of human activity and knowledge. The theory and science of lexicography should not focus on the differences regarding the specific content of all these works, but on aspects that unite them and are common to all of them. In this regard, some of the core characteristics of lexicography as an independent discipline are discussed together with its complex relation to other disciplines. Lexicographical theory is understood as a systematic set of statements about its subject field. Finally, the article argues that the fact that this theory may seem too abstract and difficult to some working lexicographers does not in itself invalidate its independent scientific status, although a close relation between theory and practice is recommended.
\end{abstract}

Keywords: LEXICOGRAPHY, LEXICOGRAPHICAL THEORY, FUNCTION THEORY, ACADEMIC STATUS OF LEXICOGRAPHY, INDEPENDENT STATUS OF LEXICOGRAPHY, INTERDISCIPLINARY VOCATION OF LEXICOGRAPHY, DICTIONARIES, LEXICOGRAPHICAL WORKS, UTILITY TOOLS

Opsomming: Gedagtes oor die akademiese status van die leksikografie. Twee hoofkampe het ontwikkel met betrekking tot die filosofiese en akademiese status van die leksikografie: een wat die leksikografie beskou as 'n onafhanklike wetenskaplike dissipline, en die ander wat so 'n wetenskaplike status teenstaan. Hierdie artikel bespreek sommige van die argumente van die tweede kamp en redeneer dat die leksikografie as 'n onafhanklike wetenskaplike dissipline beskou behoort te word. Die redenasie is gebaseer op die feit dat die onderwerpsveld van die leksikografie verskillend is van onderwerpsvelde van enige ander dissipline, insluitende die linguistiek. Hiervolgens is die konsep van 'n leksikografiese werk breër as die meer beperkte konsep van 'n woordeboek. Leksikografiese werke, insluitende woordeboeke, word beskou as kulturele artefakte en nutsgereedskap geskep om aan die onmiddellike inligtingsbehoeftes te voldoen wat in die gemeenskap vasgestel is. Op hierdie manier het hulle gedurende die millenniums byna alle sfere van menslike bedrywigheid en kennis gedek. Die teorie en wetenskap van die leksi- 
kografie behoort nie te fokus op die verskille wat betref die spesifieke inhoud van al hierdie werke nie, maar op aspekte wat hulle verenig en algemeen aan hulle almal is. In hierdie verband word sommige van die kerneienskappe van die leksikografie as 'n onafhanklike dissipline bespreek saam met sy komplekse verwantskap aan ander dissiplines. Leksikografiese teorie word verstaan as 'n sistematiese reeks stellings oor sy onderwerpsveld. Ten slotte redeneer die artikel dat die feit dat hierdie teorie te abstrak en moeilik kan lyk vir sommige praktiserende leksikograwe, nie sy onafhanklike wetenskaplike status ongeldig maak nie, alhoewel 'n noue verwantskap tussen teorie en praktyk aanbeveel word.

Sleutelwoorde: LEKSIKOGRAFIE, LEKSIKOGRAFIESE TEORIE, FUNKSIETEORIE, AKADEMIESE STATUS VAN DIE LEKSIKOGRAFIE, ONAFHANKLIKE STATUS VAN DIE LEKSIKOGRAFIE, INTERDISSIPLINÊRE TAAK VAN DIE LEKSIKOGRAFIE, WOORDEBOEKE, LEKSIKOGRAFIESE WERKE, NUTSGEREEDSKAP

\section{Introduction}

Among scholars dealing with lexicography, there is an old and deep-rooted dispute as to the philosophical and academic status of their discipline. Two main camps have been formed: one that considers lexicography an independent scientific discipline, and another that opposes such a status. The first camp has up till now found two major expressions, the lexicographical function theory developed at the Centre for Lexicography at the Aarhus Business School, Denmark, and the systematic general theory of lexicography presented by the German scholar Herbert Ernst Wiegand. The second camp has, as is natural for a discipline not considering itself to be independent, crystallized in a variety of positions which may nevertheless be ordered into three main groups with no sharp boundaries. In the best academic tradition, most of the renowned lexicographical journals, like Lexicographica, LexicoNordica and Lexikos, publish contributions by scholars belonging to both camps, thus promoting a hopefully rich and productive discussion for the benefit of the discipline.

In their introduction to a recent book, Atkins and Rundell (2008: 4) place themselves in one of the three groups belonging to the second camp:

This is not a book about 'theoretical lexicography' — for the very good reason that we do not believe that such a thing exists. But that is not to say that we pay no attention to theoretical issues. Far from it. There is an enormous body of linguistic theory which has the potential to help lexicographers to do their jobs more effectively and with greater confidence.

Thus, Atkins and Rundell reject the very existence of any lexicographical theory, although they do not exclude the need for lexicographers to be guided by a theory, in this case linguistic theory, which, as it will be recalled, embraces many competing schools. This position is somewhat surprising, especially because one of the two authors, Atkins (1992: 4-5), in a contribution reprinted in 
Fontenelle (2008), does not deny the possibility of the concept of "theoretical lexicography":

Does theoretical lexicography exist? If this forum is to discuss its nature, we must at least grant it the benefit of the doubt ... I propose here to interpret the term theoretical lexicography in the very general sense of "a body of theory related to lexicography"... Although theoretical lexicography is certainly not synonymous with lexicology ..., nor with its daughter science lexical semantics ..., a large proportion of the decisions made by the lexicographer are linguistic decisions, and so we should consider particularly, but not exclusively, the contribution of linguistics to theoretical lexicography, and hence the role of the theoretical linguist in dictionary-making.

What is interesting here is the formulation "particularly, but not exclusively". This formulation seems to open the door for an understanding of "theoretical lexicography" as something more than just "theoretical linguistics", although this "something" is not clearly defined. We will later return to the claim that "a large proportion of the decisions made by the lexicographer are linguistic decisions", but here it is sufficient to note that the above quotation from Atkins and Rundell (2008) shows that the two authors do not deny the need for theoretical guidance, although they refer the corresponding assistance to the sphere of existing linguistic theory.

Another group of scholars, who are much closer to Atkins (1992) than to Atkins and Rundell (2008), regard lexicography as a sort of subdiscipline of linguistics and are, among others, represented by Ščerba (1940), who called for a "general theory of lexicography", though embedded in linguistics, and Reinhard Hartmann who, in several contributions, has argued for the need to develop a lexicographical theory, frequently called metalexicography. It is by no means surprising that Hartmann (2009: 90) criticizes the position taken by Atkins and Rundell (2008) on the relation between theory and practice as being full of simplifications and contradictions and that he is especially annoyed because the two authors "deprecate metalexicography as the province concerned merely with talking 'about dictionaries' ". In the same group can also be included scholars like Piotrowski (2009: 485) who advocates a "new theory on lexicography" strongly embedded in modern linguistics:

A new theory of lexicography would be one that would take seriously what we know about pragmatics and discourse, text structure, and would account for the contribution of particular textual elements to the dynamic meaning of a text, in short, the dynamics of meaning construction both in the receptive and the productive mode.

Somewhere in the midstream between the two previous groups are other lexicographers who consider themselves to be applied linguists. Meier (2003: 307), for instance, writes that "dictionary making, though often regarded as 'a special technique rather than a branch of linguistics', may be considered an instance of applied linguistics". In the same spirit can be mentioned Haensch et al. (1982), a 
book that is simply entitled Lexicography: From Theoretical Linguistics to Practical Lexicography, Landau (2001) who also discusses lexicography from the point of view of linguistics referring to it as The Art and Craft of Lexicography, as well as Ten Hacken (2009: 399) who argues that linguistics, and especially Chomskyan linguistics, should be "taken as a background" in order to consider lexicography "a scientific activity".

A third group of authors denying the independent status of lexicography is represented by the lexicographer Urdang who, on more than one occasion, has rejected any possibility of being theoretically guided when involved in practical dictionary-making. The same position is shared by Wierzbiecka (1985: 5) who claims that "lexicography has no theoretical foundation, and even the best lexicographers, when pressed, can never explain what they are doing, or why". The position taken by Urdang and Wierzbiecka may be considered a sort of capitulation to the theoretical problems and challenges facing modern lexicography.

To summarize: It seems reasonable to distinguish between three main groups of lexicographers who deny their discipline's independent scientific status: one group that does not accept any theory at all; a second group that defends the development of a lexicographical theory, or metalexicography, embedded in linguistics; and a third group claiming that practical lexicography must be guided directly by linguistic theory. It is also clear that there are no sharp boundaries between the various positions which are frequently, as Hartmann rightly states, characterized by internal contradictions. The three groups comprise a large part of the lexicographers working with general dictionaries, lexicographers who frequently have their academic background in linguistics.

Whatever one thinks of their arguments, the very denial of any independent status to their discipline implies that lexicography as a whole cannot at the present moment be considered a totally independent discipline. But this does not mean that it should not be treated as such. As mentioned above, there is also another camp of lexicographers who do consider their discipline to be independent. One of the main expressions of this camp is the work of Wiegand $(1989,1998)$, who prefers the term dictionary research (German: Wörterbuchforschung) to the term theoretical lexicography when discussing the academic status of the discipline. However, in order to keep this article within acceptable limits, the following reflections will only deal with the other main expression, i.e. the lexicographical function theory.

\section{Some basic considerations}

The term lexicography is far from clear and unambiguous. One way to pinpoint its meaning is to go back in history and determine the origin of the term, which can be found in the Greek words léksis that means "speech, word", leksikón which is a book "dealing with words" and gráphein that means "to write". In the 
light of this, lexicography would mean something like "the writing about words", i.e. a very broad definition which embraces any kind of text related to linguistics and dealing with language. However, at a certain moment in history, the terms lexicography and lexicographer became specifically related to the writing and writer of dictionaries. We do not know exactly when the two terms were first used in these senses, but undoubtedly it happened centuries ago as can be seen in the definition provided by Johnson (1755) in his Dictionary of the English Language:

Lexicographer A writer of dictionaries; a harmless drudge, that busies himself in tracing the original, and detailing the signification of words.

This definition of a lexicographer provided by Johnson is far from adequate. It goes without saying that lexicographers do "write" dictionaries but they also write other types of similar "books". In fact, only four years before the publication of Johnson's dictionary, the first volume of the French Encyclopédie was published with the complete title: Encyclopédie, ou dictionnaire raisonné des sciences, des arts et des métiers (Encyclopedia, or a Systematic Dictionary of the Sciences, Arts, and Crafts). It is noteworthy that the editors had decided to include both the word encyclopedia and the word dictionary in the very title of the book. The reason for this was not that they did not know the meaning of the two words because, among the total of 71818 articles included in the 35 volumes, there is one about encyclopedias and another about dictionaries, written by each of the two main editors, d'Alembert (1754) and Diderot (1755), respectively.

Historically, in fact, lexicography does not only comprise dictionaries, but also encyclopedias, lexica, thesauri, glossaries and a number of other types of reference works. Recently, theoretical lexicography has even started to deal with how-tos, handbooks, manuals, etc. (Tarp 2007: 177). The present-day meaning of the term lexicography cannot be traced by means of etymology or determined through definitions given by lexicographers at different moments in history. The exact scientific meaning of the word lexicography is continuously changing and can only be determined on the basis of an up-to-date knowledge of the theoretical and practical development of this branch of human activity.

Both the French Encyclopédie and Johnson's Dictionary of the English Language may be considered old lexicographical works. But in a historical perspective their 250 years make them relatively young compared to the first-known dictionaries which, as it is generally accepted, were compiled more than 4000 years ago. Since then, hundreds of thousands of different dictionaries and other lexicographical works have been published as a response to very different kinds of needs occurring in different cultures and periods. In this respect, AlKasimi (1977: 1) writes:

Dictionaries have developed not as theoretical instruments, but as practical tools. The major motives behind the rise of lexicography differ from one culture to another. Each culture fosters the development of dictionaries appropriate to its characteristic demands. 
During the centuries, these practical tools have been imprinted on clay, handwritten on papyrus or paper, type-written, printed with different technologies or, more recently, made available on compact disks, the Internet and other electronic media. They have been written in hundreds of different languages, and even in dialects. They cover almost all spheres of human activity and knowledge. They have a huge variety of purposes. They transmit knowledge between generations and within each generation. They help people to communicate in their mother tongue and between and among language communities. They assist their users with advice and instructions in order to perform manual or mental actions. In short, dictionaries and other lexicographical works have played and still play an extremely important role in our cultural and social development. To reduce this rich cultural heritage to some sort of applied linguistics or, even worse, to something that cannot be described and treated theoretically is close to barbarism.

\section{Independent subject field}

A major criterion and necessary precondition for granting an independent status to lexicography is that its subject field is different from that belonging to any other discipline. Until now, the only discipline external to lexicography that has claimed property to lexicography is linguistics. The subject field of linguistics is language, something inherent in human beings without which they would not be human beings. Although the individual languages are historical and social products, modern man is genetically predisposed to develop language skills as a means of social communication, conscious thinking and knowledge storage. Contrary to this, the subject field of lexicography is constituted by dictionaries and other lexicographical works, i.e. purely cultural artefacts produced in order to satisfy various types of human needs as AlKasimi (1977) rightly points out in the above quotation.

The claim of Atkins (1992: 5) that "a large proportion of the decisions made by the lexicographer are linguistic decisions", does not correspond to the overall historical and present practice. This may, of course, be the case with some specific dictionaries compiled by lexicographers who import linguistic principles without letting them pass through any independent lexicographical "filter", but it cannot be generalised. Hence, the study of the "characteristic demands" of each culture giving rise to the development of dictionaries is hardly a linguistic discipline. Even more so because the satisfaction of many of these demands, or needs, does not require the co-operation of a linguist, but of other types of specialists. It is enough to take a glance at some of the 71818 articles in the French Encyclopédie, which is also called a dictionary, in order to confirm this statement. In most cases, the authors of the individual articles have no specialised linguistic knowledge except for the skills that all native speakers have in their mother tongue. In this respect, it is useful to reread some 
extracts from the article Dictionnaire, authored by d'Alembert (1754), who himself had no specialised linguistic training:

It is possible to distinguish between three types of dictionary: language dictionaries, historical dictionaries, and science and art dictionaries. This subdivision could be presented from a more general point of view as dictionaries of words, dictionaries of facts and dictionaries of things. Nevertheless, we retain the first subdivision because we believe that it is more convenient and even more precise. In fact, a language dictionary, which would seem to be nothing other than a word dictionary, when well done must often be a dictionary of things and is thus a very philosophical work. [...] A science dictionary can, and must, only be a dictionary of facts, whenever the causes are unknown to us, that is, almost always. [...] Finally, a historical dictionary, assembled by a philosopher, will often be a dictionary of things. Produced by an ordinary writer, by a compiler of facts and dates, it will be but a dictionary of words.

It is difficult to see the role of a linguist when it comes to producing what d'Alembert calls "historical dictionaries" and "science and art dictionaries" related to "facts" and "things". This especially becomes clear when we study some modern dictionaries dealing with specialised fields of human knowledge. In this respect, it is somehow surprising that the International Journal of Lexicography is one of the theoretical journals that almost exclusively publish articles strongly defending the subordination of lexicography to linguistics. The journal belongs to Oxford University Press which is also responsible for the publication of a large number of excellent specialised dictionaries where it is difficult to see any relation whatsoever to linguistic theory. One of these dictionaries is the Concise Oxford Dictionary of Archaeology compiled by Timothy Darvill, Doctor and Professor of Archaeology. In his preface, Darvill (2008: vii) writes about the content and the intended user group:

This dictionary of terms is intended as a guide to words likely to be commonly encountered in the archaeological literature or in the presentation of archaeological material through lectures, television, or video films. It is thus intended primarily for those who are essentially unfamiliar with the vocabulary and technical terms used by archaeologists, for example students starting out on a career in archaeology or seeking to expand their areas of special interest, journalists popularizing the scholarly outpourings of archaeology, and other professionals who have cause to dip into the archaeological literature.

Thus, this dictionary is, according to its author, conceived for interested laypeople (journalists), semi-experts (students) and professionals who seek assistance to cope with unfamiliar terms or to expand their areas of special interest. In terms of design and content, the articles included are similar to those that can be found in thousands of other specialised dictionaries:

Gallo-Belgic ware [Ar] Vessels imported from Gaul in the late 1st century $\mathrm{BC}$ and early 1 st century $\mathrm{AD}$, usually in black or silver-grey fabrics (*terra nigra) or white fabric coated with red slip ( ${ }^{*}$ terra rubra), or a 
dense white or cream fabric like pipeclay. Close British imitations of these fabrics and forms are known, and further copying of the forms was widespread. The imported vessels often have the name of the potter stamped on the inner surface of the base, a practice imitated in Britain but usually with illegible markings.

It is difficult to see why the compilation of this dictionary should require special knowledge of linguistic theory. The author is not a linguist, but an expert in archaeology which is the topic of the dictionary. Of course, he is supposed to master general and archaeological English at a very high level and, in this respect, he can be considered a person with general linguistic knowledge. But it is not necessary to have studied linguistics and know anything about linguistic theory in order to conceive and produce the dictionary in question. On the contrary, absolutely necessary is specialised and up-to-date knowledge about archaeology (and this also implies knowledge about the discipline's specialised vocabulary because a scientific discipline cannot be learned without simultaneously learning its particular terminology). The need for this specialised, up-todate knowledge can be seen not only in the above article, but also in the following observation by Darvill (2008: x):

Archaeological interpretations are constantly changing in the light of new evidence and ongoing research; in some spheres of interest such change can be quite rapid. Accordingly, the entries included here are point-in-time statements reflecting available knowledge and accepted understandings of what are undoubtedly complicated phenomena.

As mentioned in the previous section, it is a historical fact that thousands of dictionaries like the Concise Oxford Dictionary of Archaeology and the ones that d'Alembert calls "historical dictionaries" and "science and art dictionaries" related to "facts" and "things" have been produced during the last 4000 years. To claim that the lexicographical decisions taken by the authors of these dictionaries are, to a large proportion, "linguistic decisions" is simply false. Nobody denies the important contributions made by linguists to many excellent dictionaries, but what is at stake here is the claim of linguistics for property of lexicography. The world has known quite a number of dictionaries and other lexicographical works for the production of which no specialised knowledge of linguistic theory was needed or used. This fact alone indicates that lexicography in general cannot be scientifically categorised as applied linguistics or a subdiscipline of linguistics, and it also makes it pointless to claim that "a new theory of lexicography" should be based on knowledge about pragmatics, discourse, text structure, etc. as claimed by Piotrowski (2009).

It is therefore necessary to approach the status of lexicography in another way. In this respect, two alternative approaches are possible: one viewing lexicography as being simultaneously the subdiscipline of a large number of disciplines, one of them linguistics; and another regarding it as a separate and completely independent discipline, i.e. a discipline with its own independent 
subject field and core. The first approach leads to a schizophrenic understanding of lexicography, which can only explain the differences between the various lexicographical works, but not what unites them and is common to all of them. This schizophrenic approach should therefore be rejected. Consequently, if one does not want to join the capitulationist position of Urdang and Wierzbiecka, according to which no theoretical explanation of and guidance to practical dictionary-making is possible, the only option left, justified by its specific subject field, is to treat lexicography as an independent scientific discipline characterised by a big interdisciplinary vocation. Lexicography is what is left when an abstraction is made from the specific content of the data taken from other disciplines and incorporated into its individual products.

\section{Utility tools}

The most fundamental aspects characterising all types of lexicographical works is that they are utility tools which implies that they have been produced in order to meet certain types of human needs detected in society. Dictionaries were originally invented with such needs in mind, and this fundamental relation between cultural and social needs on the one, and lexicographical works on the other hand, has not changed over the millenniums. The needs are not static, but vary from culture to culture, from epoch to epoch. And even within the same culture and epoch they cannot be viewed in an abstract way, since they are always closely related to concrete persons finding themselves in concrete situations. The same person may have different types of needs in different situations, while two persons may have different needs although they find themselves in the same type of situation. The study and typologisation of these needs in their close and dialectical relation to types of users and types of social situations are therefore the starting point for any general theory of lexicography considered as an independent branch of human scientific activity. This basic idea is what is expressed in the lexicographical function theory (cf. Bergenholtz and Tarp 2002, 2003, 2004, and Tarp 2008). It places lexicography as an independent scientific discipline within the broader framework of the social sciences.

It is a matter of course that not all human needs are lexicographically relevant. Material and physical needs cannot be met by lexicographical works, and neither can all types of psychological and mental needs. On the other hand, it is evident that the needs that can actually be satisfied lexicographically are of a great variety, a fact which is reflected in the corresponding variety of existing dictionaries and other lexicographical works. In this respect, what is common to lexicographical needs, and what separates them from all other types of needs, is that they are always needs for information which subsequently may be used for a large variety of purposes. However, information needs may be met not only by lexicographical works, but also by other types of texts such as books, text books, magazines, newspapers, etc. It is therefore necessary to fur- 
ther clarify the concept of lexicographically relevant needs. To do so, it is useful to look at the distinction, discussed by Hausmann (1977: 144), between global and punctual needs (questions) and develop it further:

The question is now: What are the dictionaries for? For what purpose are they used? Which dictionaries are particularly well suited for what functions? The simplest and most frequent type of dictionary usage is undoubtedly punctual consultation to answer a very particular question ... The second type of question, which we can call systematic in contrast to punctual, is much less frequent. It is much less common for dictionaries to be used to answer these questions.

It cannot be denied that there are some rare cases of "dictionaries" designed to meet global needs. Hausmann calls them "primary learning dictionaries" (German: primäre Lernwörterbücher), i.e. dictionaries that are supposed to be read from one end to another. However, such dictionaries may be considered exceptions which confirm the thesis that no sharp boundaries exist within the subject field of social sciences in general. On the contrary, the overwhelming number of dictionaries and other lexicographical works has been designed with another view, i.e. to be used as consultation tools to meet punctual information needs. This fact brings lexicography close to modern information science.

It is obvious that the distinction between punctual and global should not be viewed in the light of short and long, but in the broader framework of part and whole. In this respect, there are lexicographical works with long entries, such as the French Encyclopédie, and the Chinese Yongle Dadian (Xie 1408), the world's biggest lexicographical work ever compiled, which, although never published, consisted of no less than 11095 volumes partially transcribed character for character as exact copies of original texts written during the previous decades and structured according to a rhyming system for the characters, which made it possible to use the work for lexicographical consultation.

To summarize: Lexicography deals with utility tools designed to be consulted in order to satisfy punctual information needs related to specific types of users and specific types of social situations and varying from culture to culture, from epoch to epoch. In this sense, it seems very restrictive to reduce the concept of a lexicographical work to some general dictionaries to the production of which only linguists have contributed. The concept of a lexicographical work comprises all utility tools designed for this purpose and with these characteristics.

\section{The core of lexicography}

Contrary to general discourse, dictionaries do not contain information, but data from which their users may retrieve the information needed. This distinction between data and information, first introduced and discussed in detail by Wiegand $(2000,2002)$, is important because the very information retrieval is a mental and intellectual exercise whose result depends on the user's character- 
istics in terms of culture, language proficiency level, and general or specialised knowledge. Two different types of users with the same type of information need may, for instance, require different types of data in order to retrieve the same information from lexicographical data. In this respect, it is necessary to point out that the concept of lexicographical data does not correspond to the concept of data resulting from empirical research, for example, corpus analysis. The lexicographical data are supposed to be selected, elaborated and presented according to lexicographical criteria with a view to making them understandable and, hence, useful to the specific type of user, i.e. to ensure that the information retrieval can actually be accomplished.

This understanding of lexicographical data implies that these data cannot be taken over uncritically from empirical research or directly from other disciplines, among them linguistics. If the data are not subjected to a meticulous selection, elaboration and presentation process according to lexicographical criteria, there is a high risk of reaching a low-quality lexicographical product, or at least a product with a number of problems and complications in terms of user-friendliness. This is the reason why it is recommendable to have a person with specialised lexicographical training responsible for the design of dictionary concepts, the writing of instructions, the preparation of working plans and the supervision of the practical lexicographical work.

Although it is also recommendable to engage experts from the respective subject fields in the practical work, they will not themselves have the necessary academic and scientific background allowing them to take overall lexicographical decisions and supervise the work with a view of ensuring a highquality lexicographical work. This also indicates why it is problematic when Atkins (1992: 5) argues that "a large proportion of the decisions made by the lexicographer are linguistic decisions". Such a practice, even in dictionaries where specialised linguistic knowledge does have an important role to play, may lead to many unnecessary weaknesses and problems which could easily be avoided by involving a lexicographical expert in the project.

As mentioned in the previous section, what distinguishes lexicographical works from other kinds of texts which users may also use to satisfy their information needs is that they are consultation tools focusing on punctual needs. This implies that the core of lexicography does not only consist of the principles of data selection, elaboration and presentation, based on a typology of needs related to types of users and social situations. In order to fulfil their function as consultation tools, lexicographical works must also cater for a quick and easy access to the relevant data, in printed dictionaries by means of lexicographical structures and references, and in electronic ones by means of search engines and links. Hence, the principles of quick and easy data accessibility, equally related to specific types of user needs, is therefore part and parcel of the core principles integrating the independent theory of lexicography (cf. Bergenholtz 2009a, and Tarp 2009a). 


\section{The relation to other disciplines}

Lexicography should be viewed not only as an independent scientific discipline in general, but also as a discipline particularly characterised by its big interdisciplinary vocation and its co-operative and integrating nature. As already mentioned, during the last 4000 years lexicographical works have covered almost all spheres of human activity and knowledge. Historically, lexicography has emerged as an academic discipline through a dialectical interaction with other disciplines. In this complex process, it is natural that it has been influenced by these disciplines in terms of specific theories, concepts and methods.

However, the assimilation of these theories, concepts and methods borrowed from other disciplines has been highly problematic, giving rise to an endless series of uncertainties and disputes among lexicographers of the various schools and tendencies, for instance on the concept of collocation and its selection and presentation in dictionaries. In many cases, especially when linguists claiming property to lexicography have been involved, the concepts, theories and methods have been taken over uncritically and directly from these other disciplines, mainly from linguistics. This method used to assimilate concepts, theories and methods developed within other spheres of human activity is, as mentioned, highly problematic. And if lexicography is considered an independent scientific discipline, it is completely contrary to the philosophical and methodological principles guiding the relation and interaction between independent disciplines. For this reason, Tarp (2008: 12) calls for a critical attitude in the relation to and interaction with other disciplines:

This necessary interaction with other disciplines does not mean that lexicography can automatically take over the arsenal of concepts, theories and methods used by these other disciplines. The fact that the object of study is delimited, and the fact that lexicography has its own independent core distinguishing it from other disciplines, mean that all these concepts, theories and methods must be subjected to critical analysis with a view to determining what should be rejected, what can be used, and how the useful factors can be adjusted and adapted to suit the particular nature of lexicography.

This critical assimilation of concepts, theories and methods used within other disciplines is not only necessary in terms of lexicographical theory, but has a big impact on the quality of practical lexicographical works. For instance, Bergenholtz (2009b) shows that the linguistic concepts of collocation and part of speech are inadequate when designing high-quality dictionaries. Tarp (2009b) discusses why learner's lexicography cannot simply take over the concepts of beginners, and intermediate and advanced learners used within linguistics and language didactics. Likewise, Tarp (2009c) argues that the linguistic distinction between homonymy and polysemy is irrelevant in the majority of lexicographical works. And finally, Xue (2010) advocates a special lexicographical approach to the linguistic concepts of nominal countability and uncountability in production dictionaries for Chinese learners of English. These are all reasons 
why even practical lexicographical decisions cannot be handed over to linguists without specialised lexicographical instruction or training.

\section{Conclusion}

As mentioned in the introduction to this article, Atkins and Rundell (2008: 4) outright declare that they "do not believe" that a lexicographical theory exists. This statement does not only represent an "anti-theoretical stance" as Hartmann (2009: 93) rightly states. It also contradicts the fact that various more or less elaborated lexicographical theories, and even competing theories, exist and have existed for decades, and that these theories are actually guiding a number of lexicographers in their practical work. If Atkins and Rundell had said instead that they disagree with these theories, find them incomprehensible, or consider them useless for their purposes, then it would have been understandable. Maybe the explication should be found in the following quotation from Atkins (1992: 29):

For me, there are three kinds of theoretical linguists, who may or may not consider themselves theoretical lexicographers. The work of the first group is too theoretical, too abstract, or too difficult, or shows too little conception of what practical lexicography is all about, for it to be of any immediate use in dictionary-making. I believe most working lexicographers share this opinion.

This point of view seems to ignore the complex relation between theory and practice, between a science and its practical applications. Nobody has ever claimed that a science or theory should necessarily be easy to understand and applicable for immediate use. As a rule, there are a number of mediations and intermediate levels between the most abstract parts of a science or theory and its practical applications. The majority of workers at a shipyard will probably find the mathematical principles and calculations included in the science of engineering too theoretical, too abstract, and too difficult for them to be of any immediate use in their daily work. But this does not mean that they reject the value of engineering and the technical instructions they receive from their foremen and instead start building advanced ships exclusively based on their own experience and practical training.

It may be true that the majority of "working lexicographers share the opinion" that some of the lexicographical theories are too abstract and difficult. They are perfectly allowed to do so, and it should not be considered a problem or obstacle to their work. In order to successfully perform their profession, they only need theory-based dictionary concepts, lexicographical instructions and detailed working plans which constitute the lowest mediating links between practical dictionary-making and the overall theory understood as a systematically structured set of statements about lexicographical works and their relation to social and cultural needs. 
As Hartmann (2009: 90) rightly says, Atkins and Rundell (2008) "deprecate metalexicography as the province concerned merely with talking 'about dictionaries' ". Of course, it cannot be denied that a number of metalexicographers, or theoretical lexicographers, has never been engaged directly in practical dictionary-making. But this fact in itself should not invalidate their theories, just as it does not invalidate the theories of the engineers if they do not work directly in production. However, a close dialectical relation between theory and practice is without any doubt both healthy and desirable for any branch of human activity. In this respect, it should be remembered that the lexicographical function theory, which considers lexicography an independent scientific discipline, has been developed at the Aarhus-based Centre for Lexicography which, in the last two or three decades, has been actively engaged in the production of more than fifty dictionaries, of which more than half have been directly designed and supervised by members of the Centre's staff. In this Centre, theory building goes along with the conception, planning and practical production of still new types of dictionaries. It is therefore necessary to use other arguments to deny the need for an independent theory of lexicography.

The discussion about the philosophical and scientific status of lexicography should not be viewed as a dispute between "good and bad" or as a controversy of merely academic interest. It should instead be understood and treated as a rich and rewarding discussion with large and immediate practical consequences. To approach lexicography as an independent discipline means to concentrate on the development of the aspects constituting the very core of lexicography and making it unique in relation to all other academic and scientific disciplines. It means to establish the correct relation between lexicography and society with a view to detect the real user needs occurring extra-lexicographically and to find the adequate lexicographical solutions. It means to focus on the development of the principles for selection, preparation and presentation of lexicographical data and the improvement of the various types of access routes to these data. And above all, it means to strengthen lexicography's interdisciplinary vocation and its relation and cooperation with all the other disciplines and sciences which, in one way or another, are relevant to lexicography and its practical products. This cooperation has existed for more than 4000 years and there is no reason why it should not continue and be further strengthened in the future.

\section{Literature}

Al-Kasimi, Ali M. 1977. Linguistics and Bilingual Dictionaries. Leyden: E.J. Brill.

d'Alembert, Jean le Rond. 1754. Dictionnaire. Encyclopédie, ou Dictionnaire raisonné des sciences, des arts et des metiers. Tome IV: 958-969. (= d'Alembert: Dictionnaire. Article de l'Encyclopédia. http:/ /fr.wikisource.org/wiki/Article_Dictionnaire_de_l'Encyclop\%C3\%A9die)

Atkins, B.T. Sue. 1992-93. Theoretical Lexicography and its Relation to Dictionary-making. Dictionaries. Journal of The Dictionary Society of North America 14: 4-43. 
Atkins, B.T. Sue and Michael Rundell. 2008. The Oxford Guide to Practical Lexicography. Oxford: Oxford University Press.

Bergenholtz, Henning. 2009a. Hurtig og sikker tilgang til informationer. LexicoNordica 16: 29-54.

Bergenholtz, Henning. 2009b. Klassifikationen in der Linguistik und in der Lexikographie: Wortarten und Wortverbindungen. Zeitschrift für Anglistik und Amerikanistik 57(3): 275-288.

Bergenholtz, Henning and Sven Tarp. 2002. Die moderne lexikographische Funktionslehre. Diskussionsbeitrag zu neuen und alten Paradigmen, die Wörterbücher als Gebrauchsgegenstände verstehen. Lexicographica 18: 253-263.

Bergenholtz, Henning and Sven Tarp. 2003. Two Opposing Theories: On H.E. Wiegand's Recent Discovery of Lexicographic Functions. Hermes, Journal of Linguistics 31: 171-196.

Bergenholtz, Henning and Sven Tarp. 2004. The Concept of "Dictionary Usage". Dollerup, Cai (Ed.). Worlds of Words. A Tribute to Arne Zettersten. Nordic Journal of English Studies 3(1): 23-36.

Darvill, Timothy, 2008. Concise Oxford Dictionary of Archaeology. Second Edition. Oxford: Oxford University Press.

Diderot, Denis. 1755. Encyclopédie. Encyclopédie, ou Dictionnaire raisonné des sciences, des arts et des metiers. Tome V: 635-648. (= Denis Diderot 1969: Oeuvres complètes. Édition chronologique. Tome 2. Paris: Club français du livre et société encyclopédique française.)

Fontenelle, Thierry (Ed.). 2008. Practical Lexicography: A Reader. Oxford Linguistics. Oxford: Oxford University Press.

Haensch, Günther, Lothar Wolf, Stefan Ettinger and Reinhold Werner. 1982. La lexicografía. De la linquística teórica a la lexicografía práctica. Madrid: Gredos.

Hartmann, Reinhard. 2009. [Review of] B.T. Sue Atkins and Michael Rundell. The Oxford Guide to Practical Lexicography. International Journal of Lexicography 22(1): 89-94.

Hausmann, Franz Josef. 1977. Einführung in die Benutzung der neufranzösischen Wörterbücher. Romanistische Arbeitshefte 19. Tübingen: Max Niemeyer.

Johnson, Samuel. 1755. Dictionary of the English Language. London: J. \& P. Knapton.

Landau, Sidney I. 2001. Dictionaries: The Art and Craft of Lexicography. Cambridge: Cambridge University Press.

Meier, Hans H. 2003. Lexicography as Applied Linguistics. Hartmann, Reinhard (Ed.). 2003. Lexicography. Critical Concepts III: 307-318. London/New York: Routledge.

Piotrowski, Tadeusz. 2009. [Review of] Sven Tarp. Lexicography in the Borderland Between Knowledge and Non-knowledge. General Lexicographical Theory with Particular Focus on Learner's Lexicography. International Journal of Lexicography 22(4): 480-486.

Ščerba, Lev V. 1940. Towards a General Theory of Lexicography. International Journal of Lexicography 8(4): 315-350, 1995.

Tarp, Sven. 2007. Lexicography in the Information Age. Lexikos 17: 170-179.

Tarp, Sven. 2008. Lexicography in the Borderland between Knowledge and Non-Knowledge. General Lexicographical Theory with Particular Focus on Learner's Lexicography. Lexicographica Series Maior 134. Tübingen: Niemeyer.

Tarp, Sven. 2009a: Reflections on Data Access in Lexicographic Works. Nielsen, Sandro and Sven Tarp (Eds.). 2009. Lexicography in the 21st Century. In Honour of Henning Bergenholtz: 43-62. Terminology and Lexicography Research and Practice 12. Amsterdam/Philadelphia: John Benjamins.

Tarp, Sven. 2009b. The Foundations of a Theory of Learners' Dictionaries. Lexicographica. International Annual for Lexicography 25: 155-158. 
Tarp, Sven. 2009c. Homonymy and Polysemy in a Lexicographic Perspective. Bergenholtz, Henning and Thomas Herbst (Eds.). 2009. Classifications in Linguistics and Lexicography. Special Issue of Zeitschrift für Anglistik und Amerikanistik 57(3): 289-306.

Ten Hacken, Puis. 2009. What is a Dictionary? A View from Chomskyan Linguistics. International Journal of Lexicography 22(4): 399-421.

Wiegand, Herbert Ernst. 1989. Der gegenwärtige Status des Lexikographie und ihr Verhältnis zu anderen Disziplinen. Hausmann, Franz Josef, Oskar Reichmann, Herbert Ernst Wiegand and Ladislav Zgusta (Eds.). 1989. Wörterbücher. Ein internationales Handbuch zur Lexikographie/ Dictionaries. An International Encyclopedia of Lexicography/Dictionnaires. Encyclopédie internationale de lexicographie: 246-280. Handbücher zur Sprach- und Kommunikationswissenschaft, Band 5.1. Berlin/New York: Walter de Gruyter.

Wiegand, Herbert Ernst. 1998. Wörterbuchforschung. Untersuchungen zur Wörterbuchbenutzung, zur Theorie, Geschichte, Kritik und Automatisierung der Lexikographie. 1. Teilband. Berlin/New York: De Gruyter.

Wiegand, Herbert Ernst. 2000. Wissen, Wissenrepräsentationen und Printwörterbücher. Heid, Ulrich, Stefan Evert, Egbert Lehmann and Christian Rohrer (Eds.). 2000. Proceedings of the Ninth EURALEX International Congress, EURALEX 2000, Stuttgart, Germany, August 8th-12th, 2000: 15-38. Stuttgart: Institut für Maschinelle Sprachverarbeitung, Universität Stuttgart.

Wiegand, Herbert Ernst. 2002. Wissen in der Sprachlexikografie. Ein Plädoyer für einige immer noch notwendige Differenzierungen. Ezawa, Kennosuke, Wilfried Kürschner, Karl H. Rensch and Manfred Ringmacher (Eds.). 2002. Linguistik jenseits des Strukturalismus. Akten des II. OstWest-Kolloquiums Berlin 1998: 265-281. Tübingen: Gunter Narr Verlag.

Wierzbiecka, Anna. 1985. Lexicography and Conceptual Analysis. Ann Arbor: Karoma.

Xie, Jin (Ed.). 1408. Yongle Dadian 1-11,095. China.

Xue, Mei. 2010. Countable or Uncountable? That is the Question - Lexicographic Solutions to Nominal Countability in Learner's Dictionaries for Production Purposes. Lexikos 20: 540-558. 